\section{International Journal of

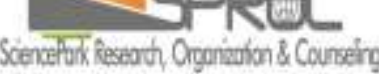

Volume 10, Issue 4, (2018) 342-349

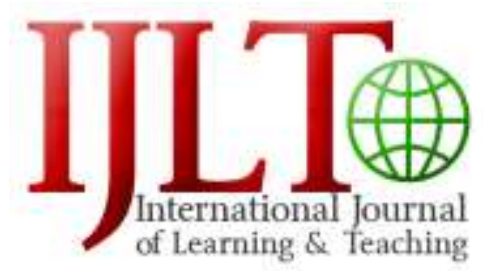

www.ij-It.eu

\title{
Grades as valid evaluation tool of academic formation
}

Gheorghe Vuc*, Politehnica University Timisoara, Piata Victoriei 2, Timisoara 300006, Romania Dan Jigoria-Oprea, Politehnica University Timisoara, Piata Victoriei 2, Timisoara 300006, Romania Felicia Baloi, Politehnica University Timisoara, Piata Victoriei 2, Timisoara 300006, Romania

\section{Suggested Citation:}

Vuc, G., Jigoria-Oprea, G. \& Baloi, F. (2018). Grades as valid evaluation tool of academic formation. International Journal of Learning and Teaching. 10(4), 342-349.

Received from October 12, 2017; revised from April 13, 2018; accepted from September 21, 2018.

Selection and peer review under responsibility of Prof. Dr. Hafize Keser, Ankara University, Ankara, Turkey.

${ }^{\circ} 2018$ SciencePark Research, Organization \& Counseling. All rights reserved.

\begin{abstract}
Before you see the faculty graduate formation, you can see its grades. Since grades are used for selection, they are very important instruments and can have serious consequences for students. Consequently, the validity of grades is an important aspect to consider, and questions concerning the functions of grades can certainly be viewed from a validity perspective. Therefore, arises a question of whether the grades indeed reflect graduated student training and especially its ability to succeed against technical problems that will be posed in front of by his professional life. Analyses carried out in several brainstorming and brainwriting sessions with students belonging to the first percentiles of their series showed that they realise the inefficiency of grades they receive. The main recommendation is to make the grading in relation to an absolute benchmark (obviously regularly adapted to technological and society developments) in the view of a correct formation for students.
\end{abstract}

Keywords: Academic grading, questionnaire, job interview.

\footnotetext{
* ADDRESS FOR CORRESPONDENCE: Gheorghe Vuc, Politehnica University Timisoara, Piata Victoriei 2, Timisoara 300006, Romania. E-mail address: gheorghe.vuc@upt.ro / Tel.: +40-256-403410
} 
Vuc, G., Jigoria-Oprea, G. \& Baloi, F. (2018). Grades as valid evaluation tool of academic formation. International Journal of Learning and Teaching. 10(4), 342-349.

\section{Introduction}

Grading systems used by teachers may be very different and may even be inaccurate. Often, they may have a reduced validity by considering non-academic criteria in granting marks. However, an employer needs to see by marks of the graduated student for the quality of the formation during the graduate studies. Obviously, before you see the faculty graduate formation, you can see its grades. Since grades are used for selection, they are very important instruments and can have serious consequences for students. Consequently, the validity of grades is an important aspect to consider, and questions concerning the functions of grades can certainly be viewed from a validity perspective (Geiser \& Santelices, 2007). Therefore, arises a question of whether the grades indeed reflect his training and especially its ability to succeed against technical problems that will be posed in front of by his professional life (Talento-Miller \& Guo, 2009; Vuc, Baloi \& Litcanu, 2015). To be useful, they must be credible notes and somewhat standardised.

\section{Goal and tools}

The authors have proposed to identify the issues related to scoring mode, the correctness of the grading system, the usefulness of notes and the degree of trust of students in the institution and in obtained grades.

Discussions were held with the students having the best results, i.e., brainstorming sessions and brainwriting meetings having the objective to identify weak elements of their preparation and grading and then to identify the solutions for improvement.

The proposed instrument for measuring the important aspects for students was a questionnaire of opinion research of our students. The questions of the questionnaire reflect issues that concern students with the best results. These issues have resulted from the aforementioned discussions.

Therefore, to assess how students see their relative quality grading achieve this preparation was consulted through a questionnaire, which contained a total of 10 questions. The content of his questionnaire is presented later.

Questions can be grouped by the following topics of interest: the form of assessment students (Q1 and Q3), the grading system correctness (Q2 and Q4), the usefulness of notes (grades) (Q9 and Q10) and the degree of trust of students in the institution and in grades obtained (Q5, Q6, Q7 and Q8). In order to be synthesised in the processing and interpretation of their answers, the answer options for each question were coded as can be seen adjoining to the answer options provided in the questionnaire.

\begin{tabular}{ll|ll}
\hline $\begin{array}{c}\text { Q1. What do you consider it important for teachers } \\
\text { in evaluating the students }\end{array}$ & \multicolumn{2}{c}{$\begin{array}{c}\text { Q2. How do you think your evaluation was made } \\
\text { compared with your own evaluation? }\end{array}$} \\
\hline Q1.A1. The abilities of communication & COM & Q2.A1. Right & COR \\
Q1.A2. The initiative & IN & Q2.A2. Not right & INCOR \\
Q1.A3. The creativity & CRE & Q2.A3. Under appreciative & SUB \\
Q1.A4. The logic & LOG & Q2.A4. Over appreciative & SUPR \\
Q1.A5. The accuracy of information & INF & Q2.A5. Generally you do not make a self- & NON \\
Q1.A6. The learning by memorisation & REPR & assessment & \\
\hline
\end{tabular}

Q3. Which way do you find more objective as examination form?

Q3.A1. The oral examination EO

Q3.A2. The written examination

Q3.A3. Distributed during a semester

examination
Q4. Do you think that, generally, the obtained marks correctly reflect your level of knowledge?

Q4.A1. Yes, completely YES

Q4.A2. Sometimes not SNO

Q4.A3. I cannot say NA 
Vuc, G., Jigoria-Oprea, G. \& Baloi, F. (2018). Grades as valid evaluation tool of academic formation. International Journal of Learning and Teaching. 10(4), 342-349.

Q3.A4. The examination carried out EP throughout the semester during classes or activities
Q4.A4. Sometimes yes

Q4.A5. Absolutely not
SYES

NO

\begin{tabular}{|c|c|c|c|}
\hline \multicolumn{2}{|c|}{$\begin{array}{l}\text { Q5. What made you to act negatively in relation } \\
\text { with a particular course? }\end{array}$} & \multicolumn{2}{|c|}{$\begin{array}{l}\text { Q6. What do you like as positive aspect about your } \\
\text { university? }\end{array}$} \\
\hline $\begin{array}{l}\text { Q5.A1. Antipathy to } \\
\text { subject content }\end{array}$ & DISC & $\begin{array}{l}\text { Q6.A1. Teaching } \\
\text { activities }\end{array}$ & LES \\
\hline $\begin{array}{l}\text { Q5.A2. Antipathy } \\
\text { towards teacher }\end{array}$ & PROF_A & $\begin{array}{l}\text { Q6.A2. The involvement } \\
\text { of teachers in teaching }\end{array}$ & TEA_LES \\
\hline $\begin{array}{l}\text { Q5.A3. The teacher } \\
\text { manner of } \\
\text { communication }\end{array}$ & PROF_C & $\begin{array}{l}\text { Q6.A3. Preparation for } \\
\text { life and labour market }\end{array}$ & LIFE_PREP \\
\hline $\begin{array}{l}\text { Q5.A4. Noisy ambiance } \\
\text { during classes }\end{array}$ & NOISE & $\begin{array}{l}\text { Q6.A4. Relations of } \\
\text { teachers with the } \\
\text { environment hiring }\end{array}$ & TEA_ENV \\
\hline $\begin{array}{l}\text { Q5.A5. The assessment } \\
\text { method }\end{array}$ & EVAL & $\begin{array}{l}\text { Q6.A5. Relations with } \\
\text { classmates }\end{array}$ & MATES \\
\hline $\begin{array}{l}\text { Q5.A6. The actuality of } \\
\text { content }\end{array}$ & ACTU & $\begin{array}{l}\text { Q6.A6. Relations with } \\
\text { teachers }\end{array}$ & TEA_REL \\
\hline
\end{tabular}

\begin{tabular}{ll|ll}
\hline $\begin{array}{l}\text { Q7. What do you consider as negative aspect about } \\
\text { your university? }\end{array}$ & \multicolumn{1}{c}{$\begin{array}{c}\text { Q8. How do you think is the ratio of effort in } \\
\text { learning and the notes from assessments? }\end{array}$} \\
\hline $\begin{array}{l}\text { Q7.A1. The material base of the } \\
\text { institution }\end{array}$ & MAT & $\begin{array}{l}\text { Q8.A1. With all the effort, it is sometimes } \\
\text { very hard to get a passing grade } \\
\text { Q8.A2. Most often get passing marks } \\
\text { effortlessly } \\
\text { Q8.A3. The effort to learn is higher than } \\
\text { the grade obtained } \\
\text { Q8.A4. The effort to learn is lower than the NO } \\
\text { mark obtained }\end{array}$ \\
$\begin{array}{l}\text { Q7.A3. The involvement of students in } \\
\text { the decision making }\end{array}$ & STUD_DEC \\
$\begin{array}{l}\text { Q7.A4. The internal rules } \\
\text { Q7.A5. The relationship with the staff } \\
\text { at the secretariat }\end{array}$ & $\begin{array}{l}\text { ROI } \\
\text { SECR }\end{array}$ & &
\end{tabular}

\begin{tabular}{|c|c|c|c|}
\hline \multicolumn{2}{|c|}{$\begin{array}{l}\text { Q9. Do you consider that the marks } \\
\text { obtained during the studies should be } \\
\text { criteria in a job interview? }\end{array}$} & \multicolumn{2}{|c|}{$\begin{array}{l}\text { Q10. In a hypothetical position as employer } \\
\text { you will want to see the graduation } \\
\text { marks of future workers? }\end{array}$} \\
\hline $\begin{array}{l}\text { Q9.A1. Yes, because they reflect } \\
\text { the readiness of the graduate }\end{array}$ & YES & $\begin{array}{l}\text { Q10.A1. Yes, because the notes say } \\
\text { something about the future employee } \\
\text { knowledge and character }\end{array}$ & YES \\
\hline $\begin{array}{l}\text { Q9.A2. In a very small measure } \\
\text { should be taken into account }\end{array}$ & SOME & $\begin{array}{l}\text { Q10.A2. Only if those notes would be } \\
\text { accompanied by a letter of } \\
\text { recommendation from a teacher }\end{array}$ & IF_DEP \\
\hline $\begin{array}{l}\text { Q9.A3. Notes are not awarded } \\
\text { objectively and should be not taken } \\
\text { into account }\end{array}$ & NO & $\begin{array}{l}\text { Q10.A3. Only if I have to make the tie } \\
\text { between two very good future } \\
\text { employees select }\end{array}$ & DEP \\
\hline $\begin{array}{l}\text { Q9.A4. No, because they do not } \\
\text { reflect the readiness of the } \\
\text { graduate }\end{array}$ & NO_FALSE & $\begin{array}{l}\text { Q10.A4. There will not interest me the } \\
\text { notes obtained during studies }\end{array}$ & NOT_INT \\
\hline
\end{tabular}

In this survey of students' opinion used for the first time in 2015 , answered a total of 44 students. It was assured anonymity of respondents to boost their sincerity of answers. The students' responses were processed and interpreted in the following paragraph. 
Vuc, G., Jigoria-Oprea, G. \& Baloi, F. (2018). Grades as valid evaluation tool of academic formation. International Journal of Learning and Teaching. 10(4), 342-349.

\section{Results and comments}

The answers given by students were processed and interpreted, considering also grouping the questions by their goal. The authors chose to present the results in graphic form, introducing in the horizontal axis the coding of answers to questions, as we can see in Section 2.

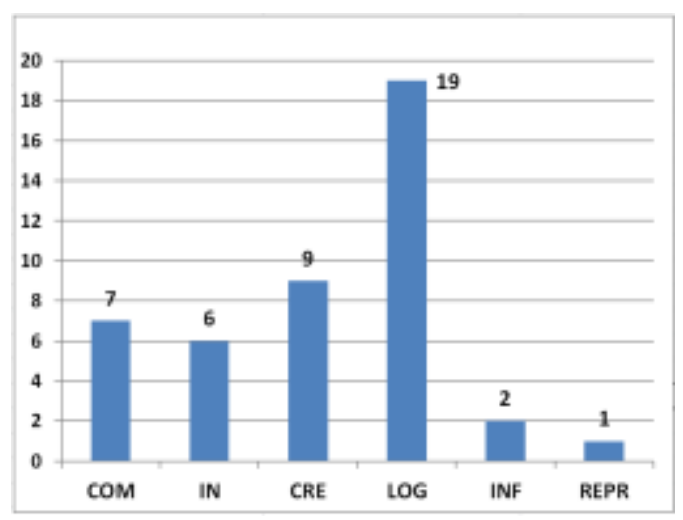

Figure 1. What do you consider it important for teachers in evaluating the students?

The answers for this questions show that a technical profile student considers the logic as the most important criterion in their evaluation and reproductive learning occupy the last place in the evaluation criteria.

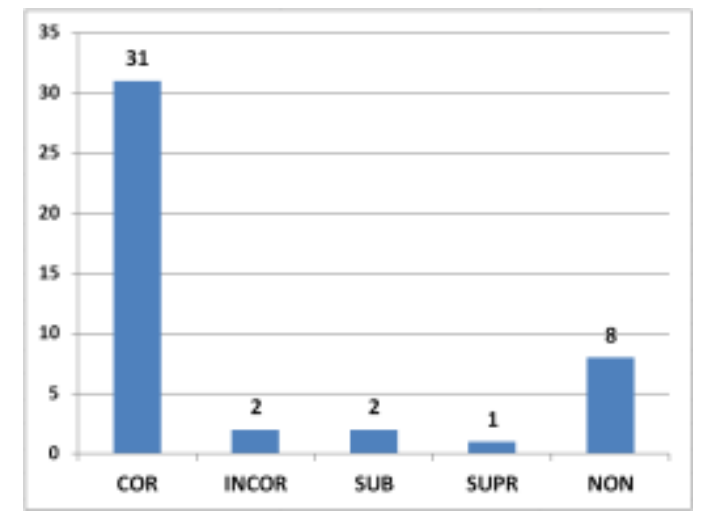

Figure 2. How do you think your evaluation was made compared with your own evaluation?

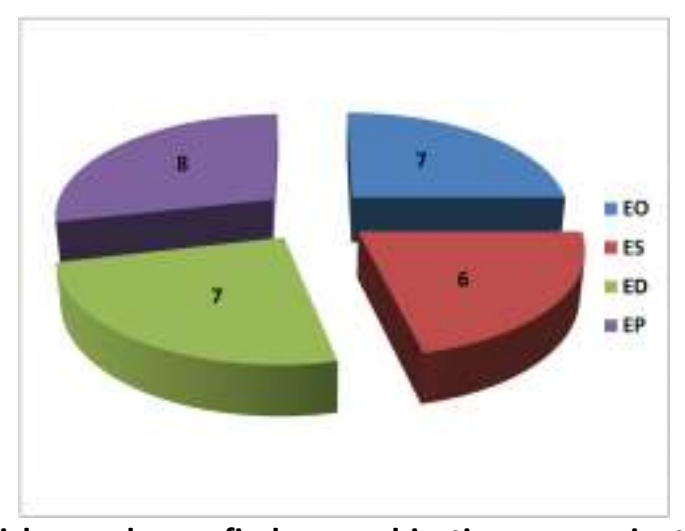

Figure 3. Which way do you find more objective as examination form? 
Vuc, G., Jigoria-Oprea, G. \& Baloi, F. (2018). Grades as valid evaluation tool of academic formation. International Journal of Learning and Teaching. 10(4), 342-349.

Although in most subjects, assessment is currently written, the students appreciate that were fair evaluated and yet question 3 shows that they would like other forms of assessment (oral, distributed, etc.).

Yet by the answers to question 3, students leave the teacher to establish a suitable evaluation form (so they respect the teacher's experience!).

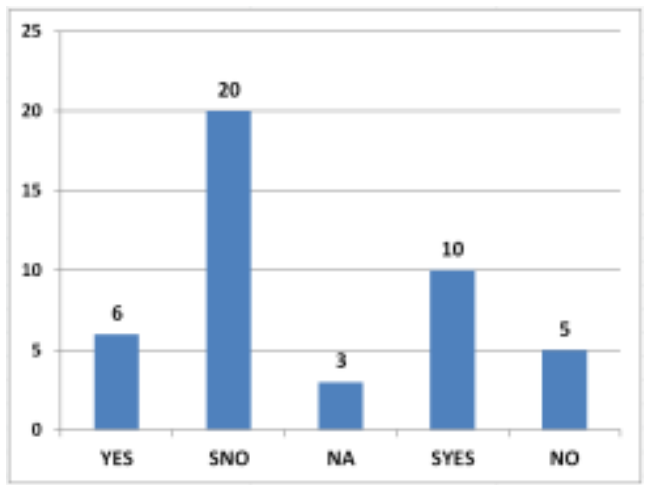

Figure 4. Do you think that, generally, the obtained marks correctly reflect your level of knowledge?

The students' answers to question 4 show their relative agreement with the correctness of the assessment established by the notes (dominates the answer 'sometimes YES' even if there is a large number for answer 'sometimes yes'). The YES dominant answer represents over $60 \%$ of the clear expressed answers.

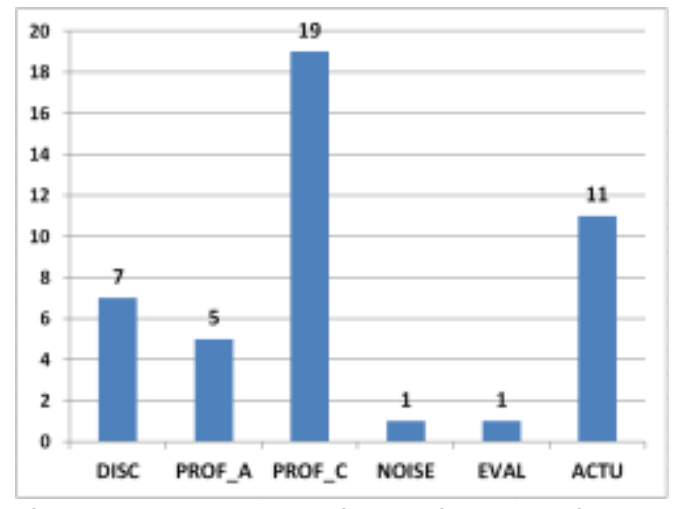

Figure 5. What made you to act negatively in relation with a particular course?

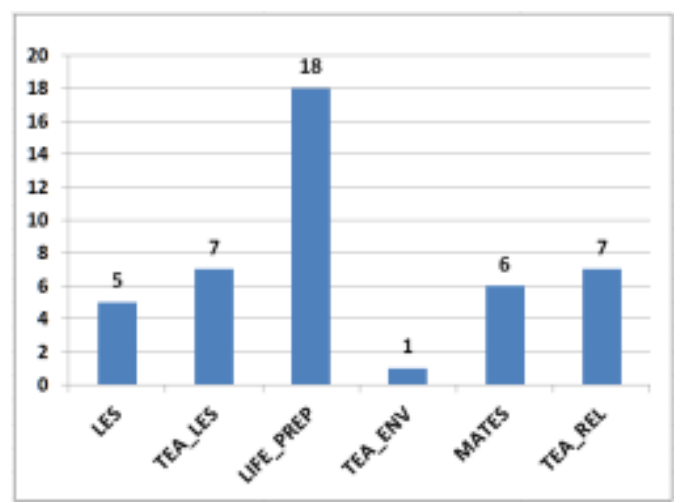

Figure 6. What do you like as a positive aspect about your university? 
Vuc, G., Jigoria-Oprea, G. \& Baloi, F. (2018). Grades as valid evaluation tool of academic formation. International Journal of Learning and Teaching. 10(4), 342-349.

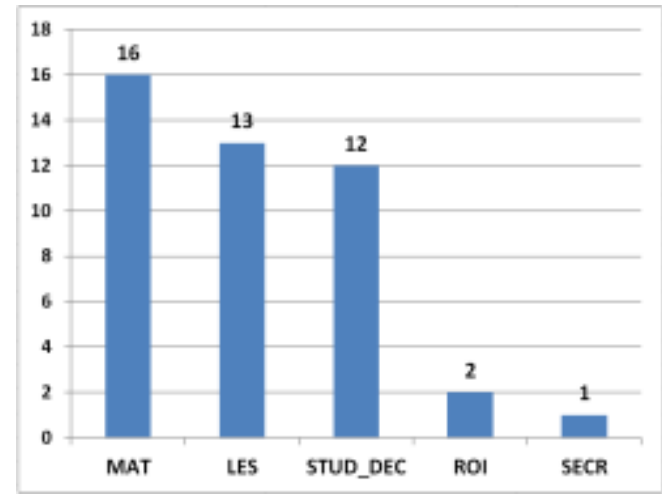

Figure 7. What do you consider as a negative aspect about your university?

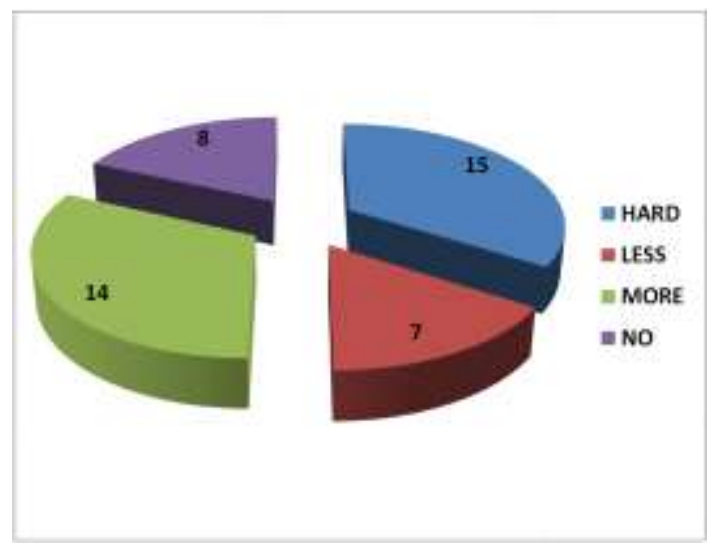

Figure 8. How do you think is the ratio of effort in learning and the notes from assessments?

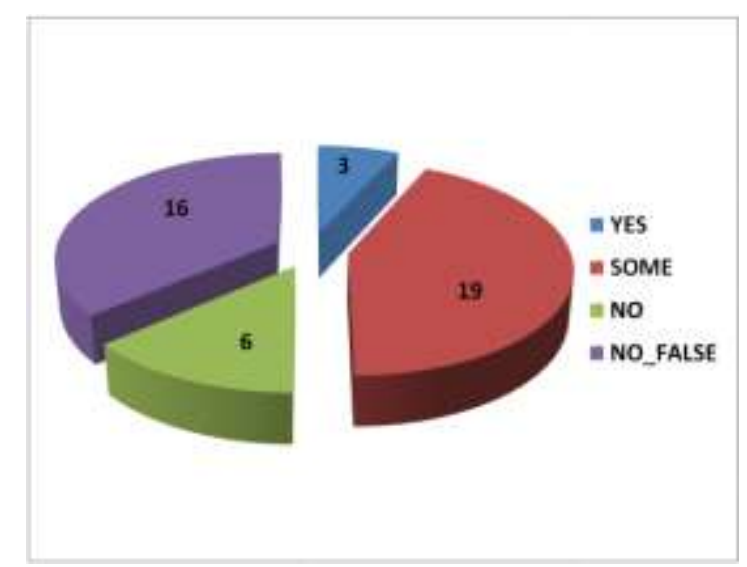

Figure 9. Do you consider that the marks obtained during the studies should be criteria in a job interview? 
Vuc, G., Jigoria-Oprea, G. \& Baloi, F. (2018). Grades as valid evaluation tool of academic formation. International Journal of Learning and Teaching. 10(4), 342-349.

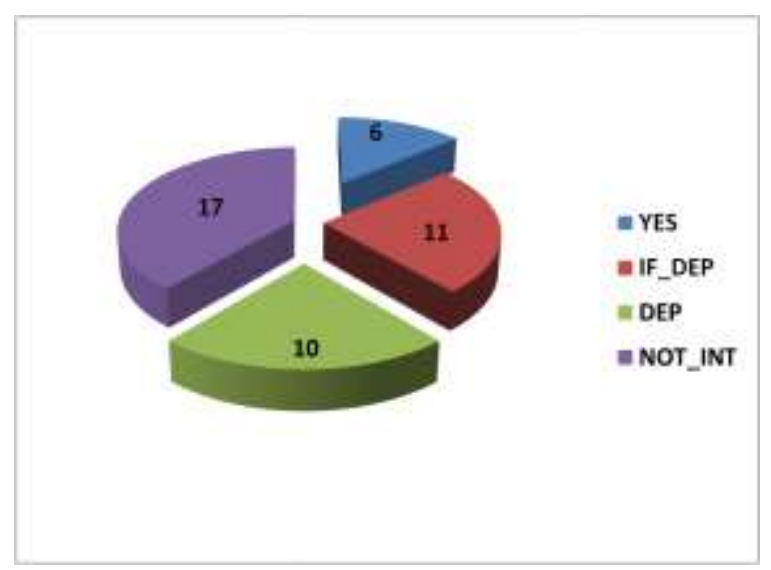

Figure 10. In a hypothetical position as an employer, you will want to see the graduation marks of future workers?

The answers to question 5 emphasise that the students' negative reaction against any particular discipline is generated predominantly by the quality of teacher communication possibly doubled by the obsolete content of the discipline. This is confirmed even by the answers given to question 7 , respectively, dissatisfaction with the quality of teaching.

The answers given for question 7 by students show that their main complaints are generated by the material base of the university, closely followed by the quality of teaching and the level of students' involvement in decision-making within the university.

The answers given by students to question 6 shows that they are aware of the importance of preparing for life as the main function of the university. At a great distance, students considered as important as the relationships with teachers, respectively, with colleagues, and even the teaching activity.

The vast majority of student responses to the eighth question show that they believe that they are making a great effort in learning compared with the obtained mark. The authors of this paper believe that in reality this subjective impression is probably caused by a lack of adaptation to the effort required.

The answers given by students to question 9 states that they consider the marks obtained during the studies are not a fair criterion for a job interview. However, this cannot be correlated with the answers to question 2, which conclude that the notes are correct. Also, the answers given by students to question 10 confirms heavily on those for question 9, dominant conclusion of the results of question 10 being that notes should be considered only as a last resort.

A possible explanation of uncorrelated responses to the questions 2 and 9 likely would be lack of confidence in the fairness of grades obtained in other universities.

More than that, diverse experiences for students' exchanges with universities in other countries have shown clear that grades of students to these faculties were different from those to the faculty of origin.

The same conclusions have resulted in several series of discussions with students from the Electric power systems specialisation of our faculty.

Extending our investigations by consultation of employers, especially those in the power system, it was considered necessary to give the importance of good initial formation for the power system engineers and the conclusions already obtained that a grading inefficiency may demobilise was confirmed. 
It appears as necessary to establish some absolute benchmark that relates the grading of students so that the information transmitted by academic grades to be more correct. Such a benchmark can be the European Credit Transfer and Accumulation System (ECTS), but even this system will only reflect the position in the hierarchy of students in their generation, or for an outside observer, even this hierarchy need to be correlated with a reference.

We consider that this absolute reference can be established with employers and may be the desired level of training but obviously not under a minimum level of formation.

\section{Conclusions}

The paper presents and analyses the results of multiple actions organised in order to determine the validity of grades as a means to establish the quality of students' training. With this goal, it was conducted an opinion polling of our students based on a questionnaire, and discussions with employers of graduates and top students.

The questionnaire answers given by students were processed and interpreted, considering also grouping the questions by their goal.

It appears as necessary to establish some absolute benchmark that relates the grading of students so that the information transmitted by academic grades to be more correct. Such a benchmark can be the ECTS, but even this system will only reflect the position in the hierarchy of students in their generation.

Also, it appears as necessary, especially for an outside observer, that this hierarchy to be correlated with a reference. We consider that this absolute reference can be established with employers and may be the desired level of training but obviously not under a minimum level of formation.

\section{References}

Geiser, S. \& Santelices, M. V. (2007). Validity of high-school grades in predicting student success beyond the freshman year. Research \& Occasional Paper Series: CSHE.6.07, Berkeley, CA: University of California.

Talento-Miller, E. \& Guo, F. (2009). When are grades no longer valid? A look at the effect of time on the usefulness of previous grades. GMAC ${ }^{\circledR}$ Research Reports, RR-09-05, February 1, 2009.

Vuc, G., Baloi, F. \& Litcanu M. (2015). Adapting methods of student evaluation and grading in electrical power engineering. Procedia Social and Behavioral Sciences, 191, 147-151. 